\title{
The Analysis of Herding Behavior in Indonesia and Singapore Stock Market
}

\author{
Aditya Andika Putra ${ }^{1}$, Eko Rizkianto ${ }^{1 *}$, Dony Abdul Chalid ${ }^{1}$ \\ ${ }^{1}$ Faculty of Economics and Business, Universitas Indonesia \\ Email: eko_rizkianto1969@yahoo.com
}

\begin{abstract}
This research aims to examine the presence of herding behavior in Indonesia and Singapore stock markets. Using CCK method and daily data of the stock population in both country's stock markets on the period of 1996-2015, this research finds the evidence of herding behavior in Indonesia and Singapore. Moreover, this research found that herding behavior in Indonesia is stronger than in Singapore. However, this study was unable to find the evidence of whether there are herding spillover from Indonesia stock market to Singapore, vice versa.
\end{abstract}

Type of Paper: Empirical

Keyword: Herding Behavior, International Financial Market, Financial Crisis

\section{Introduction}

The existence of herding behavior within a market is believed to cause a disruption on market stability (Demirer and Kutan, 2006), market unstability, fragile financial system and excessive volatility (Bikhchandani and Sharma, 2001). Since herding behavior leads to errors in the valuation of an asset, it will make the market unstable (Lao and Singh, 2011). Regarding the impact on individual market players, the existence of herding behavior in the market forces the investors to increase their portfolio diversification to reduce non-systematic risk. However, in extreme herding conditions, investors cannot diversify due to high correlation levels in the market (Economou, Kostakis, and Philippas, 2011).

This research aims to examine the presence of herding behavior in Indonesia and Singapore stock markets. By using two different stock market, this research compared the investor's herd mentality between the stock exchange in developed country and developing country. Moreover, this research examined whether there is herding spillover or whether stock market condition of one country affect the herding behavior in the other country. Economou et al. (2011) argue that herding behavior within the inter-state scope will potentially lead to instability of the stock market inside the Eurozone. The urgency is reinforced by the results of several studies that mention that ASEAN capital markets are increasingly integrated. Sharma and Wongbangpo (2002) proved that stock markets in Indonesia, Thailand, Malaysia and Singapore have longterm relationships, or in other words, integrated. Click and Pulmmer (2005) prove that by using the period after the monetary crisis of 1998, stock markets in Indonesia, Thailand, Malaysia, Singapore and the Philippines are integrated and not limited by borders between countries. 
Such evidence leads to the potential for instability of the stock market when there is a herding behavior in one of the member states. Therefore, conducting an inter-state analysis can provide benefits.

\section{Theoretical Review}

\subsection{The Theory of Herding Behavior}

Herding behavior is a condition in which a market participant follows a collective action or action from the market, regardless of the analysis that he or she has done, even if the investor consider it wrong or disagree with the market's collective action (Christie and Huang, 1995). Economou, et al. (2011) define herds behavior as a behavior of market participants that causes the alignment of actions in the market collectively due to the behavior of imitating each other. Strengthening the definitions of previous researchers, Hwang and Salmon (2004) state that herding is an investor behavior that decides to imitate the behavior of other investors or movements within the market, rather than following his own analysis and information.

Devenow and Welch (1996) and Lao and Singh (2011) state that there are two perspectives to explain the factors that cause herding behavior in a financial market. The first perspective is the dimension that assumes herding behavior is based on irrational action. The second perspective believes that herding behavior is caused by a rational action.

An irrational perspective believes that herding is a psychological phenomenon. The condition occurs when market participants ignore the analysis that has been done by the market participants themselves and follow what the market consensus (Devenow and Welch, 1996). Christie and Huang (1995) emphasize that herding occurs when market participants follow what the market consensus, even though he believes that collective market action is inappropriate. This happens because the individual does herding to reduce uncertainty and to meet the need for self-confidence (Vaughan and Hogg, 2005). Furthermore, Lao and Singh (2011) state that when investors are faced with uncertain conditions, anxiety makes it difficult for them to analyze and make rational decisions. Thus, they choose to follow the market to reduce the anxiety.

In herding perspectives as a rational act, externality, compensation and optimal decision making in a distorted state of information, is the center of attention of the cause of herding (Devenow and Welch, 1996). Bikhchandani and Sharma (2001) identified three causes of herding behavior as a rational act: imperfect information, reputation and compensation structure.

The first cause of herding behavior is imperfect information. The imperfect information theory based its understanding on how investors tend to follow other investors decision through cascades by examining previous investors' actions. Bikhchandani and Sharma (2001) argued that to invest cascade start, the number of investor who previously invested on the project must exceed as much as two compared with investor who refuse to invest. On this situation, the rational investor will invest regardless the information he owned. The second cause of herding behavior is reputation. In herding based on reputation theory, investor / analyst / fund manager will follow other player to hide their investment competences. The third cause of herding behavior is compensation structure. In herding based on compensation, market player tends to follow other market player if the they have compensation structure which based on relative performance on other market player. (Bikhchandani and Sharma, 2001). 
Chang et al. (2000) used data from developed and developing countries on their study. They found that markets developing countries (South Korea and Taiwan) contained significant herds behavior. On the other hand, they found that on stock market in developed countries (United States and Hong-Kong), there is no herds behavior. In Japan, when the stock market has negative return, there is an indication of a herding behavior. However, there is no herding behavior when the stock market produces a positive return. Similar research was conducted by Economou et al. (2011) on stock markets in Portugal, Italy, Greece and Spain. They discover that developing countries have less developed financial systems and regulation, markets dominated by large investors, markets affected by fluctuating capital inflows and non-optimal market microstructure causing herding behavior to tend to be more prevalent in developing countries.

In terms of relationship between stock markets, Chiang and Zheng (2010) argued it would be beneficial to add impact analysis of another country's market condition on herding behavior, since the economic activity between countries are inseparable. Chiang and Zheng (2010) used data from 18 countries and added an analysis of the contagion effect. They found that in developed countries, except the United States and in Asia, there were indications of herding when the market was in a state of increasing and declining. However, their study confirmed that there was no indication of herding in Latin America. They also found that the crisis that triggered herding in a country that was the source of the crisis, could result in a contagion effect in neighboring countries.

Tan et al (2008) explains that it is important to know whether investors in a stock market make investment decisions based on investment decisions of investors in other markets. In line with herding spillover effect, Galariotis et al. (2015) explains that herding spillover is a condition when herding behavior in a market is caused by events in other markets. Klein (2013) provides the view that an analysis related to the spillover in herding is an analysis of the impact of the spread of inter-market crisis. Bekaert et al (2014) explains how spillover impacts spread to other countries. They argued that a dispersion was explained by the wake-up call hypothesis. The hypothesis explains that if a country is hit by a crisis, then other market participants in the country will reassess the possibility of something similar happening in their country. Therefore, countries with poor fundamental conditions will be affected by the same crisis.

\section{Research Methodology}

\subsection{Data}

This research used the population of stock that listed in Indonesia Stock Exchange and Singapore Stock Exchange which obtained from Reuters Data Stream. To check the robustness of this research, the authors deliberately used two definitions of market return: equally weighted market return which calculated by averaging all stock return regardless their market capitalization, and value weighted market return by using capitalization weighted index. The authors used daily data from 1st January 1996 until 31st December 2015. For the value weighted analysis, Jakarta Composite Index and FTSE ST All Share Index were used as the market return.

\subsection{Method}

There are several methods to identify the existence of herding behavior. However, the two most commonly used are the method proposed by Christie and Huang (1995) or CH 
and method proposed by Chang, Cheng, and Khorana (2000) or CCK. In this study, the authors used the CCK method by using the Cross-Section Absolute Deviation (CSAD) as a dispersion variable. CCK model based their theory on CAPM Black (1972) who predicts a linear relationship between assets systematic risk / sensitivity and market return:

$$
E_{i}\left(R_{i}\right)=\gamma_{0}+\beta_{i} E_{t}\left(R_{m}-\gamma_{0}\right)
$$

Where $\gamma_{0}$ is zero beta portfolio, $\beta_{\mathrm{i}}$ is systematic risk of i security. Hence, due to sensitivity difference on each asset $\left(\beta_{\mathrm{i}}\right)$ the model of rational asset pricing model predicts that return dispersion, value of deviation of each stock return to market portfolio, (CSAD), between individual assets have a positive and linear relationship to the market portfolio return. This due to differences of asset's sensitivity or reaction to changes in market returns (Beta), so that when there is an increase in the absolute value of market returns, the dispersion return of individual assets in the market will increase linearly. However, if there is herding behavior within a market, where market participants tend to follow the collective action of the market and ignore the analysis that has been done by himself, then the behavior will increase the correlation between asset returns, thus causing dispersion among asset returns in a market decrease or at least increase but less than proportional (Chang, Cheng, and Khorana, 2000).

Therefore, Chang, Cheng, and Khorana (2000) use the calculation of return dispersion as:

$$
C S A D_{t}=\frac{\sum_{t=1}^{N}\left|R_{i, t}-R_{m, r}\right|}{N}
$$

Where $\operatorname{CSAD}_{t}$ is Cross Section Absolute Deviation in period $t, \mathrm{R}_{(\mathrm{i}, \mathrm{t})}$ as daily Return on stock $\mathrm{i}$ in period $t, R_{(m, t)}$ equally or value weighted return in period $t$ and $N$ represents Number of shares in market portfolio. To examine the existence of herding behavior in the stock market on the condition as a whole, then the we do regression of the model as follows:

$$
C S A D_{i, t}=\alpha+\gamma_{1}\left|R_{m, t}\right|+\gamma_{2} R_{m, t}^{2}+\varepsilon_{t}
$$

Since CAPM Black (1972) assumes that there is a linear and positive relationship between market return and CSAD, if in a market there is no herding behavior the coefficient $\gamma_{1}$ will be positive and the value of coefficient $\gamma_{2}$ is zero. Whereas in the presence of herding, there is a non-linear relationship so that the value of $\gamma_{2}$ will be negatively significant.

To test the effect of stock market conditions on herding behavior in other country stock market between Indonesia and Singapore, the authors utilised the method which proposed by Galariotis, Rong and Spyrou (2015). The model is based on model proposed in equation 3 and add square market return of other country $\left(\mathrm{R}_{(\mathrm{j}, \mathrm{t}}^{2}\right)$. then the authors performed regression of the model as follows:

$$
C S A D_{i, t}=\alpha+\gamma_{1}\left|R_{m, t}\right|+\gamma_{2} R_{m, t}^{2}+\gamma_{3} R_{j, t}^{2}+\varepsilon_{t}
$$

If there is an influence of other country market condition on herding behavior, the $\gamma \_3$ coefficient value should be significant negative. 


\subsection{Operational of Variables}

\subsubsection{Dependent Variables}

Dependent variable from this research is Cross Section Average Deviation (CSAD), namely the value of deviation of each stock return to market portfolio return in t period. We calculate CSAD similar with the CCK calculation (Equation 2). This research used two definition of market portfolio return calculation, equally weighted market return and value weighted market return. Equally weighted market return is calculated as follow:

$$
T R_{i}=\sum_{i}^{N} W_{i}\left(\ln \left(\frac{P_{t, i}}{P_{t-1, i}}\right)\right)
$$

Where: $\quad \mathrm{TR}_{\mathrm{i}}=$ Total return of equally weighted portfolio

$$
\begin{array}{lll}
\mathrm{W}_{\mathrm{i}} & =\quad \text { The weight of each stock at equally weighted portfolio } \\
\mathrm{P}_{\mathrm{t}, \mathrm{i}} & =\text { The price of each stock at } \mathrm{t} \text { period }
\end{array}
$$

While Value weighted market return is calculated as follow:

$$
R_{t}=\ln \frac{P_{t}}{P_{t-1}}
$$

Where: $\quad \mathrm{R}_{\mathrm{t}}=$ Daily return of value weighted portfolio

$$
\mathrm{P}_{\mathrm{t}}^{\mathrm{t}} \quad=\quad \text { Stock index at } \mathrm{t} \text { period }
$$

\subsubsection{Independent Variables}

There are two independent variables on this research, namely absolute market portfolio return $\left(\left|\mathrm{R}_{\mathrm{m}, \mathrm{t}}\right|\right)$, to test the linear correlation between market portfolio return and return dispersion, and the squared market portfolio return $\left(\mathrm{R}_{\mathrm{m}, \mathrm{t}}^{2}\right)$ to test if there is non-linear relationship between market portfolio return and return dispersion.

\section{Results}

\subsection{Descriptive Statistics}

Table 1 is a statistical summary of the data used in this study. The data was divided into two groups: equally weighted market return (Panel A) and value weighted return (Panel B). For equally weighted (Panel A), Indonesia has higher average return than Singapore which has negative returns. On the other hand, volatility (St. deviation) from Indonesia is lower than Singapore. For value weighted (Panel B), Indonesia has a higher market return compared to equally weighted. CSAD (dispersion) variable is also higher with value weighted calculation compared with equally weighted, it shows that average dispersion of stock return is more dispersed with value weighted calculation.

\subsection{Results and Discussion}

Panel A of Table 2 shows the regression results equally weighted return method for both countries. From the results obtained for the entire period, the indication herding behavior existence in 
Table 1. Descriptive Statistics

\begin{tabular}{lcccc}
\hline \multicolumn{2}{c}{ Indonesia } & & \multicolumn{2}{c}{ Singapore } \\
\hline & CSAD & Rm & CSAD & Rm \\
\hline Panel A: Equally weighted market Return & & & -0.000377 \\
Mean & 0.021210 & 0.000055 & 0.022019 & -0.000059 \\
Median & 0.018585 & 0.000061 & 0.021319 & 0.093685 \\
Maximum & 0.110522 & 0.098205 & 0.086519 & -0.096735 \\
Minimum & 0.000000 & -0.096276 & 0.000000 & 0.012210 \\
St. Deviation & 0.012306 & 0.011501 & 0.008901 & 0.079974 \\
Skewness & 1.750090 & -0.214400 & 0.878888 & 12.37764 \\
Kurtosis & 9.214338 & 14.89658 & 7.736772 & 5219 \\
Observation & 5219 & 5219 & 5219 & 0.000042 \\
Panel B: Value weighted market Return & & & 0.000056 \\
Mean & 0.022879 & 0.000420 & 0.023060 & 0.072754 \\
Median & 0.020344 & 0.000163 & 0.022233 & -0.086330 \\
Maximum & 0.118592 & 0.131277 & 0.084151 & 0.011254 \\
Minimum & 0.000000 & -0.127321 & 0.000000 & -0.375606 \\
St. Deviation & 0.013160 & 0.015617 & 0.008530 & 8.894934 \\
Skewness & 1.732811 & -0.215789 & 0.992285 & 4262 \\
Kurtosis & 9.326855 & 11.28456 & 9.845965 & 4262 \\
Observation & 5219 & 5219 & & \\
\hline & & & & \\
\hline
\end{tabular}

the Indonesia stock market is proven. Singapore is also shown to have herding behavior in its stock market. This is evidenced by the coefficient $\mathrm{R}_{\mathrm{m}, \mathrm{t}}^{2}$ which is also significantly negative at $1 \%$ significance level. Therefore, it can be concluded that the regression result from the first model in the whole period is consistent with the hypothesis that there are herding behavior in the Indonesia and Singapore stock markets. It shows that investors in both countries ignore the analysis and tend to follow the decisions of other investors in the market over the entire period (1996-2015). This finding is consistent with the findings of Chiang and Zheng (2010).

Comparison between the coefficients $\mathrm{R}_{\mathrm{m}, \mathrm{t}}^{2}$ between the two countries can be used to find out whether herding behavior is stronger in developing countries (Economou et al., 2011Lao and Singh, 2011). The findings show that in the whole period, Indonesia had a lower $\mathrm{R}_{\mathrm{m}, \mathrm{t}}^{2}$ coefficient than Singapore. Therefore, it can be concluded that herding behavior in Indonesia, as a developing market, is stronger than Singapore as a developed market. The findings are in accordance with the statement of Economou et al. (2011) who state developing countries that are characterized by several things. First, the weak financial systems and regulation. Second, the markets are dominated by institutional investors and incompetent retail investor. Third, its dependence or exposure to flows of the international market. Hence, those factors made herding behavior is more likely to occur in developing countries than developed countries (Economou et al., 2011)

For the Asian crisis period 1997-1998, there is an indication of herding behavior in both countries. This is evidenced by the coefficients $\mathrm{R}_{\mathrm{m}, \mathrm{t}}$ of the two countries that are negatively significant. Interesting thing was found in the period of observation of global crisis (subprime mortgage) 2008-2011. In that period, with insignificant $\mathrm{R}_{\mathrm{m}, \mathrm{t}}^{2}$ coefficients, Indonesia has not shown any herding behavior in the stock market. Whereas, on the other side of Singapore there is proven herding behavior and shows that herding behavior is stronger when in subprime crisis period. 
Table 2. Herding Behavior in Indonesia and Singapore Stock Market

\begin{tabular}{|c|c|c|c|c|}
\hline & Constant & $\mathbf{R}_{\mathrm{m}, \mathrm{t}}$ & $\mathbf{R}_{\mathrm{m}, \mathrm{t}}^{2}$ & $\mathbf{R}^{2}$ Adj. \\
\hline \multicolumn{5}{|l|}{ Panel A: Equally weighted market Return } \\
\hline \multicolumn{5}{|l|}{ Indonesia } \\
\hline Whole period (1996-2015) & $\begin{array}{l}0.012481 \\
(53.31226)^{* * *}\end{array}$ & $\begin{array}{l}1.361113 \\
(30.17158)^{* * *}\end{array}$ & $\begin{array}{l}-5.939916 \\
(-7.642854)^{* * *}\end{array}$ & $66.03 \%$ \\
\hline Asian Crisis (1997- 1998) & $\begin{array}{l}0.019820 \\
(9.371985)^{* * *}\end{array}$ & $\begin{array}{l}1.206827 \\
(6.637226)^{* * *}\end{array}$ & $\begin{array}{l}-4.820839 \\
(-1.828553)^{*}\end{array}$ & $62.93 \%$ \\
\hline Subprime Crisis (2008-2011) & $\begin{array}{l}0.011881 \\
(29.80230)^{* * *}\end{array}$ & $\begin{array}{l}1.027897 \\
(17.00765)^{* * *}\end{array}$ & $\begin{array}{l}-1.284339 \\
(-0.790470)\end{array}$ & $69.49 \%$ \\
\hline \multicolumn{5}{|l|}{ Singapore } \\
\hline Whole period (1996-2015) & $\begin{array}{l}0.015930 \\
(69.73422)^{* * *}\end{array}$ & $\begin{array}{l}0.879145 \\
(23.84033)^{* * *}\end{array}$ & $\begin{array}{l}-4.792401 \\
(-6.233035)^{* * *}\end{array}$ & $50.38 \%$ \\
\hline Asian Crisis (1997- 1998) & $\begin{array}{l}0.014965 \\
(12.65671)^{* * *}\end{array}$ & $\begin{array}{l}0.815107 \\
(7.462129)^{* * *}\end{array}$ & $\begin{array}{l}-2.945840 \\
(-2.124228)^{* *}\end{array}$ & $69.86 \%$ \\
\hline Subprime Crisis (2008-2011) & $\begin{array}{l}0.017924 \\
(31.71221)^{* * *}\end{array}$ & $\begin{array}{l}1.158644 \\
(13.31895)^{* * *}\end{array}$ & $\begin{array}{l}-5.594070 \\
(-3.471907)^{* * *}\end{array}$ & $59.54 \%$ \\
\hline \multicolumn{5}{|l|}{ Panel B: Value weighted market Return } \\
\hline Whole period (1996-2015) & $\begin{array}{l}0.013722 \\
(49.08561)^{* * *}\end{array}$ & $\begin{array}{l}0.943439 \\
(30.26057)^{* * *}\end{array}$ & $\begin{array}{l}-1.814153 \\
(-4.604459)^{* * *}\end{array}$ & $57.62 \%$ \\
\hline Asian Crisis (1997- 1998) & $\begin{array}{l}0.020036 \\
(11.28521)^{* * *}\end{array}$ & $\begin{array}{l}1.032346 \\
(9.948328)^{* * *}\end{array}$ & $\begin{array}{l}-3.073678 \\
(-3.051853)^{* * *}\end{array}$ & $68.19 \%$ \\
\hline Subprime Crisis (2008-2011) & $\begin{array}{l}0.012359 \\
(29.30358)^{* * *}\end{array}$ & $\begin{array}{l}0.720983 \\
(18.92308)^{* * *}\end{array}$ & $\begin{array}{l}-0.101086 \\
(-0.144507)\end{array}$ & $78.33 \%$ \\
\hline \multicolumn{5}{|l|}{ Singapore } \\
\hline Whole period (1996-2015) & $\begin{array}{l}0.017365 \\
(71.24536)^{* * *}\end{array}$ & $\begin{array}{l}0.769910 \\
(17.44727)^{* * *}\end{array}$ & $\begin{array}{l}-1.693107 \\
(-1.146778)\end{array}$ & $46.59 \%$ \\
\hline Subprime Crisis (2008-2011) & $\begin{array}{l}0.018632 \\
(33.91337)^{* * *}\end{array}$ & $\begin{array}{l}0.938668 \\
(15.75592)^{* * *}\end{array}$ & $\begin{array}{l}-2.328083 \\
(-2.442056)^{* *}\end{array}$ & $60.42 \%$ \\
\hline
\end{tabular}

Note: The table is the result of regression coefficient estimation by using newey west method from model: $\operatorname{CSAD}_{\mathrm{i}, \mathrm{t}}=\alpha+\gamma_{1} \mid \mathrm{R}_{\mathrm{m}, \mathrm{t}}\left[+\gamma_{2} \mathrm{R}_{\mathrm{m}, \mathrm{t}}^{2}+\varepsilon_{\mathrm{t}}\right.$. Panel A is the result of the calculation using equally weighted market return and panel B by using the calculation of value weighted market return. ***,**,* describes statistically significant at levels of $1 \%, 5 \%$, and $10 \%$.

In the context of Indonesia, the results show that when the subprime mortgage crisis, stock market participants in Indonesia prefer self-analysis to follow other investors' decisions when deciding where to invest. Since the investors in Indonesia see more long-term investment in the stock market, when there is a rapid decline on the market price, the investors would not feel panic (Lao and Singh, 2011). This statement is supported by two facts. First, the Government of Indonesia issued a Government Regulation, Law of the Republic of Indonesia No. 4 of 2008, concerning for financial system security net to reduce uncertainty and panic at Indonesian stock market during the 2008 global financial crisis. Secondly, there is an indication of stronger global financial crisis impact on Singapore's economy. Singapore's Industrial Production Index had lost $13.68 \%$ while Indonesia only lost $1.9 \%$.

For the method of calculating the value weighted method (Panel B), Indonesia is consistent with the findings by using equal weighted (panel A) that there is evidence of herding behavior. Conversely, there is no evidence of herding behavior in Singapore. Even though there is an inconsistency of the result with the hypothesis of herding behavior, it proves the statement of 
Table 3. Herding Behavior Spillover

\begin{tabular}{|c|c|c|c|c|c|}
\hline & Constant & $\mathrm{R}_{\mathrm{m}, \mathrm{t}}$ & $\mathrm{R}_{\mathrm{m}, \mathrm{t}}^{2}$ & $\mathrm{R}_{\mathrm{j}, \mathrm{t}}^{2}$ & $\mathrm{R}^{2} \mathrm{Adj}$ \\
\hline \multicolumn{6}{|c|}{ Panel A: Equally weighted market Return } \\
\hline \multicolumn{6}{|l|}{ Indonesia } \\
\hline \multirow[t]{2}{*}{ Whole period (1996-2015) } & 0.012390 & 1.332406 & -6.118589 & 2.113636 & $66.70 \%$ \\
\hline & $(53.77247)^{* * *}$ & $(29.70705)^{* * *}$ & $(-7.607208) * * *$ & $(4.087405)^{* * *}$ & \\
\hline \multirow[t]{2}{*}{ Asian Crisis (1997- 1998) } & 0.019255 & 1.195753 & -5.967101 & 2.464135 & $65.18 \%$ \\
\hline & $(9.570583)^{* * *}$ & $(6.440457)^{* * *}$ & $(-2.077718)^{* *}$ & $(2.812825)^{* * *}$ & \\
\hline \multirow[t]{2}{*}{ Subprime Crisis (2008-2011) } & 0.011886 & 1.029598 & -1.242711 & -0.127662 & $69.46 \%$ \\
\hline & $(29.92587)^{* * *}$ & $(17.20242)^{* * *}$ & $(-0.726521)$ & $(-0.169149)$ & \\
\hline \multicolumn{6}{|l|}{ Singapore } \\
\hline \multirow[t]{2}{*}{ Whole period (1996-2015) } & 0.015935 & 0.882208 & -4.775097 & -0.232054 & $50.38 \%$ \\
\hline & $(69.78151)^{* * *}$ & $(23.87531)^{* * *}$ & $(-6.239799) * * *$ & $(-1.154288)$ & \\
\hline \multirow[t]{2}{*}{ Asian Crisis (1997- 1998) } & 0.014952 & 0.814287 & -2.961514 & 0.069253 & $69.70 \%$ \\
\hline & $(12.67160)^{* * *}$ & $(7.326257)^{* * *}$ & $(-2.160727)^{* *}$ & $(0.178626)$ & \\
\hline \multirow[t]{2}{*}{ Subprime Crisis (2008-2011) } & 0.017929 & 1.160743 & -5.491150 & -0.421510 & $59.50 \%$ \\
\hline & $(31.80501)^{* * *}$ & $(13.30492)^{* * *}$ & $(-3.535608) * * *$ & $(-0.613113)$ & \\
\hline \multicolumn{6}{|c|}{ Panel B: Value weighted market Return } \\
\hline \multicolumn{6}{|c|}{ Indonesia } \\
\hline \multirow{2}{*}{ Whole period (1996-2015) } & 0.013370 & 0.836579 & -2.340637 & 0.152675 & $59.52 \%$ \\
\hline & $(46.93420)^{* * *}$ & $(23.36345)^{* * *}$ & $(-2.489392)^{* *}$ & $(0.412967)$ & \\
\hline \multirow[t]{2}{*}{ Subprime Crisis (2008-2011) } & 0.012388 & 0.723075 & 0.015434 & -0.382910 & $78.34 \%$ \\
\hline & $(29.49400)^{* * *}$ & $(19.00764)^{* * * *}$ & $(0.020594)$ & $(-0.976393)$ & \\
\hline \multicolumn{6}{|l|}{ Singapore } \\
\hline \multirow[t]{2}{*}{ Whole period (1996-2015) } & 0.017328 & 0.768105 & -1.982345 & 0.455347 & $46.65 \%$ \\
\hline & $(71.36342)^{* * *}$ & $(17.72436)^{* * *}$ & $(-1.356446)$ & $(1.428913)$ & \\
\hline \multirow[t]{2}{*}{ Subprime Crisis (2008-2011) } & 0.018600 & 0.935716 & -2.632096 & 0.439376 & $60.45 \%$ \\
\hline & $(34.34122)^{* * *}$ & $(15.67393)^{* * *}$ & $(-2.940651)^{* * *}$ & 0.835550 & \\
\hline
\end{tabular}

Economou et al. (2011) that the likelihood of herding behavior in developing countries is more likely than those in developed countries.

When compared to the results of the equally weighted equation weighted value, Indonesia demonstrates robust conclusions that there was herding throughout the 1997-1998 Asian period and crisis. However, there was no herding occured in the 1997-1998 global crisis. As for Singapore, there are differences regarding the existence of herding behavior in the whole period.

\subsubsection{Herding Behavior Spillover}

To detect the impact of stock market conditions in one country on herding behavior in another country, the authors followed the variables on Galariotis et al. (2015) by adding additional variables $\mathrm{R}_{\mathrm{j}, \mathrm{t}}^{2}$, namely squared market returns on in other countries from the standard model. Based on the regression results in Table 3, all $\gamma_{3}$ coefficient show insignificant or significant but positive sign result, indicating robust results that there is no effect of one countries market condition on herding behavior in other countries, either from the Singapore stock market to 
Indonesia or Indonesia to Singapore. In panel A, for Indonesia there is no herding spillover both from Singapore (Indonesia) to Indonesia (Singapore) in whole periods and in crisis periods. This suggests that investors' behavior to follow other investors in the Indonesia (Singapore) stock market is not affected by the market conditions at the Singapore (Indonesia) stock market either for the whole period or during the Asian crisis period and subprime mortgage crisis.

\section{Conclusion}

This research aims to examine the presence of herding behavior in Indonesia and Singapore stock markets. This research concludes that there is an evidence of herding behavior in both Indonesia and Singapore stock markets during 1996 to 2015 periods. However, during the global financial crisis in 2008, there is no indication of herding behavior in Indonesia stock exchange. However, in overall period, Indonesia stock market as a developing country has stronger herding behavior compare to Singapore stock market as a developed country. Moreover, this research finds there is no influence of market condition in one country on herding behavior in other countries (herding spillover-effect), from Indonesia to Singapore and Singapore to Indonesia robustly throughout the whole period as well as during the Asian crisis and subprime crisis.

This study can only identify where herding behavior exists, which can be considered as the study's limitation. It is encouraged for future research to study factors that may influence investors' herding behavior, especially in Indonesia stock market, where the likelihood of herding behavior is high. Hence, those research can provide concrete solutions to related party to reduce herding behavior in stock market which has negative effect on financial market stability. Herding behavior can lead to escalation of correlation between returns of one stock and the other stocks, reducing the benefit of diversification. Therefore, if herding behavior exist, it will need a large number of stocks to get the same level of portfolio diversification, compared to when there is no herding behavior. For the institutional investor who are characterized as professional investor, we recommend to diversify their asset to alternative investment, such as asset backed securities or private equity investment that has low correlation to equity market movement to manage their portfolio risk.

\section{References}

Bekaert, G., Ehrmann, M., Fratzscher, \& Mehl, A. (2014). The Global Crisis and Equity Market Contagion. The Journal of Finance, 2597-2649.

Bikhchandani, S., \& Sharma, S. (2001). Herd Behavior in Finacial Markets. IMF Staff Papers, 279-310.

Black, F. (1972). Capital Market in Equilibrium with Restricted Borrowing. Journal of Business, 444-455.

Chang, E., Cheng, J., \& Khorana, A. (2000). An Examination of Herd Behavior in Equity Markets: An International Prespective. Journal of Banking \& Finance, 1651-1679. 
Chiang, T., \& Zheng, D. (2010). An Empirical Analysis of Herd Behavior in Global Stock Markets. Journal of Banking \& Finance, 1911-1921.

Christie, W., \& Huang, R. (1995). Following the Pied Piper: Do Individual Returns Herd around the Market? Financial Analysis Journal, 31-37.

Click, R., \& Plummer, M. (2003). Stock Market Integration in ASEAN after the Financial Crisis. The International Centre for the Study of Eas Asian Development Working Paper, $1-34$.

Demirer, R., \& Kutan, A. (2006). Does Herding Behaior Exist in Chinese Stock Markets? Journal of International Financial Markets, Institutions \& Money, 123-142.

Devenow, A., \& Welch, I. (1996). Rational Herding in Financial Economics. European Economic Review, 603-615.

Economou, F., Kostakis, A., \& Philippas, N. (2011). Cross-country Effects in Herding Behavior: Evidence from Four South European Markets. Jurnal of International Financial Markets, Institutions \& Money, 443-460.

Galariotis, E. C., Rong, W., \& Spyrou, S. I. (2015). Herding on Fundamental Information: A Comparative Study. Journal of Banking \& Finance, 589-598.

Hwang, S., \& Salmon, M. (2004). Market Stress and Herding. Journal of Empirical Finance, 585-616.

Klein, A. C. (2013). Time-variations in Herding Behavior: Evidence from a Markov Switching SUR Model. Journal of International Market, Institutions \& Money, 291-304.

Lao, P., \& Singh, H. (2011). Herding Behavior in the Chinese and Indian Stock Markets. Journal of Asian Economics, 495-506.

Sharma, S., \& Wongbangpo, P. (2002). Long-ter Trends and Cycles in ASEAN Stock Markets. Review of Financial Economics, 299-315.

Tan, L., Chiang, T. C., Mason, J., \& Neiliing, E. (2008). Herding Behaviour in Chinese Stock Markets: An Examination of A and B Shares. Pacific-Basin Finance Journal, 61-77.

Vaughan, G. M., \& Hogg, M. A. (2005). Introduction to Social Psychology. Australia: Pearson. 